\title{
PENGARUH CORPORATE SOCIAL RESPONSIBILITY TERHADAP MANAJEMEN LABA DENGAN LEVERAGE DAN GROWTH SEBAGAI VARIABEL CONTROL PADA INDUSTRI FARMASI YANG TERDAFTAR DI BURSA EFEK INDONESIA
}

\author{
Marissa Putriana, Susi Artati, Venny Junica Utami \\ Fakultas Ekonomi, Universitas Batanghari
}

\begin{abstract}
This research aimed to examine the influence of Corporate Social Responsibility on earnings management. The population in this research is the pharmaceutical company on the Indonesia stock exchange. Samples are selected using a purposive sampling method. The data used in this research is 6 companies for the period of 2012-2016. The method of data analysis used multiple linear regression. The result of this research showed that Corporate Social Responsibility is not a significant effect and have a positive relationship towards the earnings management.
\end{abstract}

Keywords : corporate social responsibility, earning management, leverage, growth

\section{PENDAHULUAN}

Suatu Perusahaan dalam menjalankan aktivitas bisnisnya tentu memiliki tanggung jawab terhadap pemangku kepentingan, baik pihak internal perusaahaan maupun pihak eksernal. Pemangku kepentingan yang dapat terlibat dalam suatu bisnis yaitu pemilik atau pemegang saham, kreditor, karyawan, pemasok (supplier), konsumen, komunitas, serta lingkungannya itu sendiri. Tanggung jawab yang dilakukan perusahaan ini merupakan tanggung jawab sosial dengan melihat seberapa besar kesadaran perusahaan mengenai bagaimana keputusan bisnisnya dapat mempengaruhi masyarakat (Arna, 2015).

Tanggung jawab sosial atau yang dikenal dengan istilah Corporate Social Responsibility (CSR), pada kenyataannya lebih berorientasi pada masyarakat dan bisnis. Perusahaan yang selalu menargetkan profit terhadap bisnisnya apakah dapat pula memberikan tanggung jawab atas hak masyarakat umum, mengingat besarnya pengaruh bisnis yang dilakukan. Menurut Arna (2015), apabila perusahaan tidak memperhatikan seluruh faktor yang mengelilinginya, mulai dari karyawan, konsumen, lingkungan dan sumber daya alam sebagai satu kesatuan yang saling mendukung suatu sistem, maka tindakan itu akan mengakhiri eksistensi perusahaan itu sendiri. Tanggung jawab sosial ini dapat diartikan sebagai komitmen industri untuk mempertanggungjawabkan dampak dari operasi atau aktivitas yang dilakukan perusahaan dalam aspek sosial, ekonomi, dan lingkungan, serta menjaga agar dampak tersebut memberikan manfaat kepada masyarakat dan lingkungannya. (Adisetiawan, 2011)

Tanggung jawab sosial perusahaan itu sendiri dapat digambarkan sebagai ketersediaan informasi keuangan dan non keuangan berkaitan dengan interaksi organisasi dengan lingkungan fisik dan lingkungan sosialnya, yang dapat dibuat dalam laporan tahunan perusahaan atau laporan sosial terpisah. Perusahaan yang melakukan tanggung jawab sosial mungkin akan kehilangan kesempatan investasi dalam sektor keuangannya, karena perusahaan harus mengorbankan kesempatan tersebut untuk melakukan kegiatan tanggung jawab sosial. Jika tanggung jawab sosial dilakukan secara konsisten, maka perusahaan yang melakukannya akan dianggap sebagai perusahaan yang beroperasi untuk kesejahteraan masyarakat.

Awalnya, tanggung jawab sosial ini memang sengaja dilakukan oleh pihak perusahaan secara sukarela untuk membangun citra positif di masyarakat, tetapi pada tahun 2007, Indonesia mewajibkan perusahaanperusahaan yang memiliki usaha berkaitan dengan sumber daya alam untuk melaksanakan tanggung jawab sosial tersebut. Kebijakan ini juga memperkuat pendapat bahwa tanggung jawab sosial tidak lagi menjadi domain dari perusahaan besar, melainkan merupakan suatu keharusan bagi semua pihak yang menjalankan bisnis. Hal ini dapat dilihat pada Undang-undang No.40 mengenai Perseroan Terbatas pasal 74 yang menyatakan bahwa perusahaan yang melakukan kegiatan usaha di bidang atau yang berkaitan dengan sumber daya alam wajib melakukan tanggung jawab sosial dan lingkungan. Selain itu, berdasarkan Undang-undang Penanaman Modal No. 25 Tahun 2007 pasal 15 disebutkan bahwa setiap penanam modal berkewajiban 
melaksanakan tanggung jawab sosial perusahaan dan pada pasal 34 disebutkan pula bahwa perusahaan yang tidak memenuhi kewajiban yang telah ditentukan dalam pasal 15 akan dikenakan sanksi administratif berupa peringatan tertulis, pembatalan kegiatan usaha, pembekuan kegiatan usaha dan fasilitas penanaman modal, atau pencabutaan kegiatan usaha atau fasilitas penanaman modal. Dalam laporan tahunan perusahaan, corporate social responsibility ini tentunya menjadi salah satu strategi bisnis perusahaan untuk meningkatkan labanya. Laba merupakan salah satu indikator yang terdapat pada laporan keuangan perusahaan yang digunakan para investor untuk mengambil keputusan. (Adisetiawan dan Surono, 2016)

Secara umum manajemen laba didefinisikan sebagai upaya manajer perusahaan untuk mengintervensi atau mempengaruhi informasi dalam laporan keuangan dengan tujuan untuk mengelabui stakeholder yang ingin mengetahui kinerja dan kondisi perusahaan. Istilah intervensi dipakai sebagai dasar sebagian pihak untuk menilai manajemen laba sebagai kecurangan. Sementara pihak lain tetap menganggap aktivitas rekayasa manajerial ini bukan sebagai kecurangan. Alasannya, intervensi itu dilakukan manajer perusahaan dalam kerangka standar akuntansi, yaitu masih menggunakan metode dan prosedur akuntansi yang diterima dan diakui secara umum. Manajemen laba terjadi ketika para manajer menggunakan keputusan tertentu dalam laporan keuangan dan mengubah transaksi untuk mengubah laporan keuangan sehingga menyesatkan stakeholder yang ingin mengetahui kinerja ekonomi yang diperoleh perusahaan atau untuk memengaruhi hasil kontrak yang menggunakan angka-angka akuntansi yang dilaporakan dalam laporan keuangan.

Manajemen laba memberikan fleksibilitas bagi manajer untuk melindungi diri maupun perusahaan dalam mengantisipasi kejadian-kejadian tak terduga untuk keuntungan pihak-pihak yang terlibat dalam kontrak. Watt dan Zimmerman (1978) dalam Arna (2015) menetapkan manajemen laba sebagai tindakan manajer dalam menggunakan kebijakan akuntansi terhadap pelaporan angka-angka akuntansi yang tidak sesuai dengan kondisi ekonomi perusahaan yang sebenarnya dan menyesatkan pihak investor dalam mengambil keputusan ekonomi dengan adanya angka laba tersebut. Menurut Scott (2003), banyak penyebab yang membuat pihak manajer melakukan manajemen laba, salah satunya yaitu manajer akan berusaha mengatur laba bersih agar dapat memaksimalkan bonus yang diperolehnya. Selain itu, manajer dapat juga mengurangi laba bersih yang dilaporkan agar nilai pembayaran pajak yang lebih kecil.

Adanya aktivitas tanggung jawab sosial ini dapat membuat pihak manajemen yang berada dalam perusahaan lebih leluasa untuk melakukan praktik manajemen laba, karena dengan dilakukannya kegiatan CSR akan membuat respon positif dimata investor maupun masyarakat sehingga dapat menutupi kecurangankecurangan yang telah dilakukan pihak manajer. Di sisi lain, pengungkapan kegiatan tanggung jawab sosial dalam laporan tahunan membuat informasi keuangan yang terdapat pada laporan keuangan lebih jelas dan transparan. Menurut Kim, Park, dan Wier (2012), Corporate Social Responsibility merupakan pelaporan dari aktivitas tanggung jawab sosial yang umum bagi investor, pelanggan, dan pihak stakeholder lainnya untuk menuntut transparansi yang lebih besar mengenai semua aspek bisnis. Laporan tahunan menjadi lebih terpercaya bagi investor maupun pihak yang menggunakan laporan tersebut dalam pengambilan keputusan. Perusahaan yang bertanggung jawab secara sosial yang mengeluarkan usaha dan sumber daya dalam memilih dan menerapkan praktek corporate social responsibility untuk memenuhi harapan etis para pemegang saham dalam masyarakat, cenderung membatasi penggunaan manajemen labanya sehingga memberikan investor informasi keuangan yang lebih transparan dan dapat diandalkan.

Penelitian mengenai hubungan antara tanggung jawab sosial (CSR) dan manajemen laba ini pertama kali dieksplorasi oleh Chih, Shen, dan Kang (2008) serta Prior, Surroca, dan Tribo (2008). Penelitian yang dilakukan Prior et al. (2008) menunjukkan hasil bahwa terdapat pengaruh positif antara praktik manajemen laba (earnings management) dengan corporate social responsibility. Sedangkan Chih et al. (2008) menemukan adanya hubungan negatif antara CSR dengan manajemen laba, ketika manajemen laba diproksikan dengan perataan laba (income smoothing). Putri (2012) dan Palguna Putra (2013) juga membuktikan adanya hubungan negatif dan signifikan antara pengungkapan CSR terhadap manajemen laba. Nastiti (2010) dan Fan (2013) menemukan bahwa terdapat pengaruh negatif dan tidak signifikan antara CSR dan manajemen laba. Menurut Nastiti (2010), penerapan CSR di Indonesia tidak menjamin lebih sedikitnya praktek manajemen laba yang dilakukan, hal ini disebabkan adanya perbedaan cara pandang dan budaya masyarakat, serta supremasi hukum yang belum sempurna. Yip et al. (2011) menemukan adanya hubungan 
negatif dan signifikan antara CSR dan manajemen laba pada perusahaan minyak dan gas, serta adanya hubungan positif dan signifikan pada perusahaan pangan. Makni Gargouri et al. (2010) menemukan adanya hubungan positif antara kinerja sosial perusahaan dengan manajemen laba. Patten et al. (2003) menemukan adanya hubungan positif dan signifikan antara pengungkapan lingkungan dan manajemen laba. Penelitian ini mengacu kepada penelitian yang dilakukan oleh Kim, Park, dan Wier (2012) yang meneliti keterkaitan antara tanggung jawab sosial dan kualitas laba yang diukur melalui manajemen laba. Sama dengan halnya penelitian pada Chih et al. (2008), penelitian Kim et al. (2012) juga menemukan adanya hubungan negatif antara CSR dengan manajemen laba. Penelitian ini sendiri memiliki beberapa perbedaan dengan penelitian yang dilakukan oleh Kim et al. (2012).

Pada penelitian Kim et al. (2012), corporate social responsibility sebagai variabel independen diukur melalui kinerja CSR dengan menggunakan CSR Scores berdasarkan informasi dari KLD Research \& Analytics, yang pada penelitian ini CSR diukur menggunakan pengungkapan CSR dengan menggunakan CSR Index yang pengungkapannya disyaratkan pada GRI (Global Reporting Initiative). Sedangkan manajemen laba sebagai variabel dependen diukur menggunakan discretionary accrual, real activities manipulation, dan Accounting and Auditing Enforcement Releases (AAERs), yang pada penelitian ini diukur menggunakan discretionary accrual. Proksi Accounting and Auditing Enforcement Releases (AAERs) tidak digunakan dalam penelitian ini dikarenakan AAERs merupakan aturan yang berada di Amerika untuk mengidentifikasi perusahaan yang menjadi subjek dari tindakan paksaan SEC atas pelanggaran GAAP. Banyaknya kontradiktif dan variasi hasil penelitian terdahulu seperti yang telah disebutkan diatas, maka disusunlah penelitian ini dengan membahas pengaruh corporate social responsibility terhadap manajemen laba dengan Leverage dan Growth sebagai Variabel Control pada Industri Farmasi yang terdaftar di Bursa Efek Indonesia. Tujuan penelitian ini adalah Untuk mengetahui bagaimana pengaruh Pengungkapan Corporate Social Responsibility terhadap Manajemen Laba Dengan Leverage dan Growth Sebagai Variabel Control Pada Perusahaan Farmasi Yang Terdaftar Di Bursa Efek Indonesiaperiode 2012-2016.

\section{Landasan Teori}

Teori Agensi (Agency Theory)

Menurut Salno dan Baridwan (2000:19), konsep manajemen laba menggunakan pendekatan teori keagenan (agency theory) yang menyatakan bahwa "praktek earning management dipengaruhi oleh konflik antara kepentingan manajemen (agent) dan pemilik (principal) yang timbul karena setiap pihak berusaha untuk mencapai atau mempertimbangkan tingkat kemakmuran yang dikehendakinya". Konflik tersebut dapat muncul akibat pemilik sebagai prinsipal tidak dapat memonitor aktivitas manajemen sehari-hari untuk memastikan bahwa pihak manajemen selaku agent bekerja sesuai dengan keinginan pemegang saham (pemilik). Perbedaan informasi antara manajemen dan pemilik perusahaan dapat memberikan kesempatan kepada manajer untuk melakukan manajemen laba yang dapat menyesatkan pemilik perusahaan mengenai kinerja ekonomi perusahaan. Hendriksen dan Breda (2000) mengemukakan bahwa teori keagenan menimbulkan masalah-masalah yang disebabkan oleh informasi yang tidak lengkap atau informasi asimetris, yaitu ketika tidak semua keadaan diketahui oleh kedua pihak dan sebagai akibatnya terdapat konsekuensikonsekuensi tertentu yang tidak dipertimbangkan oleh keduanya.

\section{Teori Legitimasi}

Menurut Lindblom (1993), legitimasi merupakan suatu kondisi dimana sistem nilai sebuah entitas sama dengan sistem nilai dari sistem sosial masyarakat dimana suatu entitas menjadi bagian dari masyarakat. Teori legitimasi ini dapat diterapkan pada perusahaan yang melakukan kegiatan tanggung jawab sosial. Perusahaan menjadi bagian dari suatu komunitas dan lingkungannya itu sendiri. Dampak yang ditimbulkan dari aktivitas perusahaan tersebut, akan sangat berpengaruh terhadap masyarakat sekitar, sehingga apa yang dilakukan oleh pihak perusahaan akan kembali lagi kepada masyarakat tersebut. Oleh karena itu, manajemen perusahaan membutuhkan dukungan dari lingkungan masyarakat yang kondusif agar perusahaan dapat beroperasi dengan tenang. Dengan kata lain, perusahaan memerlukan legitimasi dari masyarakat sekitarnya. Hal ini juga sejalan dengan legitimacy theory yang menyatakan bahwa perusahaan memiliki kontrak dengan 
masyarakat untuk melakukan kegiatannya berdasarkan nilai-nilai justice, dan bagaimana perusahaan menanggapi berbagai kelompok kepentingan untuk melegitimasi tindakan perusahaan (Tilt, 1994, dalam Hanifa dan Cooke, 2005).

\section{Corporate Social Responsibility (CSR)}

Menurut The World Business Council for Sustainable Development (WBCSD), tanggung jawab sosial merupakan sebuah komitmen bisnis untuk memberikan konstribusi bagi pembangunan ekonomi berkelanjutan, melalui kerja sama dengan para karyawan serta perwakilan perusahaan, komunitas setempat maupun masyarakat umum untuk meningkatkan kualitas kehidupan dengan cara yang bermanfaat, baik bagi kelangsungan bisnis perusahaan maupun untuk pembangunan. Tanggung jawab sosial yang dilakukan perusahaan ini berhubungan erat dengan pembangunan berkelanjutan, dimana suatu organisasi, terutama perusahaan, dalam melaksanakan aktivitasnya harus mendasarkan keputusannya tidak hanya berdasarkan dampaknya dalam aspek ekonomi, misalnya tingkat keuntungan atau deviden, melainkan juga harus menimbang dampak sosial dan lingkungan yang timbul dari keputusannya itu, baik untuk jangka pendek maupun untuk jangka yang lebih panjang.

\section{Manajemen Laba}

Manajemen laba (earnings management) merupakan suatu tindakan manajemen perusahaan untuk mempengaruhi laba yang dilaporkan agar terbentuk informasi mengenai keuntungan ekonomis (economic advantage) yang sebenarnya tidak dialami oleh perusahaan (Merchant, 1989). Selain itu, terdapat definisi earnings management menurut Sugiri (1998) yang dikutip oleh Arna (2016):

a. Definisi sempit Manajemen laba didefinisikan sebagai sikap atau tindakan manajer untuk mengatur komponen discretionarry accruals dalam menentukan besar kecilnya laba melalui metode akuntansi.

b. Definisi luas Manajemen laba merupakan suatu tindakan manajer untuk meningkatkan atau menurunkan laba yang dilaporkan saat ini atas suatu unit yang menjadi tanggung jawabnya tanpa mengakibatkan peningkatan atau penurunan profitabilitas ekonomi jangka panjang tersebut.

\section{Hipotesis}

Adapun hipotesis dari penelitian ini adalah sebagai berikut: diduga terdapat pengaruh Corporate Social Responsibility terhadap Manajemen Laba dengan Leverage dan Growth sebagai Variabel Control Pada Perusahaan Farmasi Yang Terdaftar Di Bursa Efek Indonesia periode 2012-2016.

\section{METODE}

Jenis data yang digunakan dalam penelitian ini adalah data sekunder berupa laporan keuangan dan laporan berkelanjutan perusahaan yang terdaftar di Bursa Efek Indonesia. Data sekunder ini diperoleh situs resmi Bursa Efek Indonesia (www.idx.com). Populasi dalam penelitian ini adalah Perusahaan Farmasi di Bursa Efek Indonesia.Sampel yang dipilih menggunakan metode purposive sampling dengan kriteria sampel yang akan digunakan yaitu : (1) Perusahaan farmasi yang terdaftar di BEI untuk tahun 2012 - 2016. (2) Memiliki data yang lengkap berkaitan dengan variabel yang akan digunakan dalam penelitian ini. Adapun sampel yang digunakan dalam penelitian dapa diliha pada Tabel 1 berikut :

Tabel 1

\section{Sampel Penelitian}

\begin{tabular}{lll}
\hline No & Kode & Nama Perusahaan \\
\hline 1 & DVAL & Darya-Varia Laboratoria Tbk \\
2 & KAEF & Kimia Farma (Persero) Tbk \\
3 & KLBF & Kalbe Farma Tbk \\
4 & MERK & Merk Tbk \\
5 & PYFA & Pyridam Farma Tbk \\
6 & TSPC & Tempo Scan Pacific Tbk \\
\hline
\end{tabular}


Sebelum dilakukan regresi data yang telah dikumpulkan akan dianalisis dengan melakukan statistik deskriptif. Statistik deskriptif memberikan gambaran atau deskripsi suatu data yang dilihat dari nilai rata-rata (mean), standar deviasi, 38 varian, maksimum, dan minimum (Ghozali, 2011). Nilai mean adalah nilai ratarata dari setiap variabel penelitian yang digunakan dalam suatu penelitian. Uji asumsi klasik yang dipergunakan dalam penelitian ini antara lain uji normalitas, uji heteroskedasitas, dan uji autokorelasi. Analisis data untuk pengujian hipotesis dengan menggunakan analisis regresi berganda. Analisis regresi berganda dalam penelitian ini digunakan untuk mengetahu pengaruh Corporate Social Responsibility (CSR) terhadap manajemen laba. Model persamaan regresi yang akan diuji dalam penelitian ini adalah: $\mathrm{Y}=\alpha+\beta 1$ CSRIit $+\beta 2 \mathrm{LEVit}+\beta 3 \mathrm{MBit}+\varepsilon$ it

Keterangan $: \mathrm{Y}=$ Manajemen Laba; CSRIit $=$ CSR index perusahaan $\mathrm{i}$ tahun bersangkutan; LEVit $=$ Leverage perusahaan i tahun bersangkutan; Mbit =Market to Book equity ratio perusahaan i tahun bersangkutan; $\varepsilon=$ Error item; $\alpha=$ Konstanta; $\beta 1-\beta 3=$ Koefisien regresi

\section{Uji Hipotesis}

Uji hipotesis ini terdiri dari tiga bagian, bagian pertama akan dibahas mengenai uji $\mathrm{F}$, bagian kedua uji $\mathrm{t}$ dan yang terakhir mengenai uji koefisien determinasi $\left(\mathrm{R}^{2}\right)$.

1. Uji Simultan (Uji F)

Uji statistik $\mathrm{F}$ pada dasarnya menunjukkan apakah semua variabel independen atau bebas yang dimasukkan dalam model mempunyai pengaruh secara bersama-sama terhadap variabel dependen (Ghozali, 2011). Pengujian dilakukan dengan menggunakan tingkat signifikansi $0,05(\alpha=5 \%)$.

2. Uji Parsial (Uji t)

Uji hipotesis dilakukan dengan uji t. Uji statistik t dalam penelitian ini digunakan untuk menunjukkan seberapa jauh pengaruh satu variabel independen secara individual dalam menerangkan variasi variabel dependen. Pengujian ini menguji signifikansi koefisien variabel independen dalam memprediksi variabel dependen. Tingkat signifikansi yang digunakan dalam penelitian ini adalah $0,05(\alpha=5 \%)$.

3. Koefisien Determinasi $\left(\mathrm{R}^{2}\right)$

Koefisien determinasi $\left(\mathrm{R}^{2}\right)$ ini digunakan untuk menggambarkan seberapa jauh kemampuan model menjelaskan variasi variabel dependen. Nilai koefisien determinasi $\left(R^{2}\right)$ berkisar antara $0<R^{2}<1$.

\section{Operasional Variabel \\ Manajemen Laba}

Manajemen laba dalam penelitian ini diukur menggunakan proksi akrual modal kerja dengan penjualan , Utami (2005). Adapun rumus yang digunakan sebagai berikut.

Manajelem Laba $(\mathrm{ML})=$ Akrual Modal Kerja $(\mathrm{t}) /$ Penjualan periode $(\mathrm{t})$

Akrual Modal Kerja $=\Delta \mathrm{AL}-\Delta \mathrm{HL}-\Delta \mathrm{Kas}$

Keterangan: $\Delta \mathrm{AL}=$ Perubahan aktiva lancar pada periode $\mathrm{t} ; \Delta \mathrm{HL}=$ Perubahan hutang lancar pada periode $\mathrm{t}$ dan $\Delta \mathrm{Kas}=$ Perubahan kas dan ekuitas kas pada periode $\mathrm{t}$

\section{Corporate Social Responsibility}

CSR adalah pengungkapan informasi yang berkaitan dengan lingkungan di dalam laporan tahunan perusahaan. CSR diukur menggunakan Corporate Social Responsibility Index (CSRI). Instrumen pengukuran CSRI yang akan digunakan dalam penelitian ini mengacu pada instrumen Global Reporting Initiative (GRI). GRI merupakan sebuah jaringan berbasis organisasi yang telah mempelopori perkembangan dunia, paling banyak menggunakan laporan berkelanjutan dan berkomitmen terus menerus melakukan perbaikan dan penerapan diseluruh dunia. Dalam GRI Versi 3.0 ini, informasi CSR dikelompokkan ke dalam enam kategori, yaitu: aspek ekonomi, kinerja lingkungan, praktek tenaga kerja dan pekerjaan yang layak, hak asasi manusia, masyarakat, dan tanggung jawab produk. Kategori-kategori tersebut terbagi dalam 79 item pengungkapan. Pengukuran CSRI ini dilakukan melalui content analysis dalam mengukur variety dari CSRI. Pendekatan ini pada dasarnya menggunakan pendekatan dikotomi, yaitu setiap kategori informasi pengungkapan CSR dalam instrumen penelitian diberi skor 1 jika kategori informasi yang diungkapkan ada dalam laporan tahunan, dan 
nilai 0 jika kategori informasi tidak diungkapkan di dalam laporan tahunan. Selanjutnya, skor dari setiap kategori informasi Sustainability Report dijumlahkan untuk memperoleh keseluruhan skor untuk setiap perusahaan. Pengukuran dengan menggunakan rumus sebagai berikut:

CSRIy $=\left(\frac{\Sigma \mathrm{XKy}}{\mathrm{ny}}\right)$

Keterangan : CSRIy =Corporate Social Responsibility Indeks perusahaan y, $\Sigma$ Xky $=$ Total dari dummy variable: 1 = jika kategori Sustainability Report k diungkapkan; $0=$ Jika kategori Sustainability Report k tidak diungkapkan. ny = Jumlah item untuk perusahaan y, ny $=79$

\section{Leverage}

Leverage adalah kemampuan yang dimiliki oleh perusahaan untuk memenuhi segala kewajiban finansialnya yang dapat diperoleh melalui pihak ketiga yaitu pihak selain investor jika perusahaan tersebut dilikuidasi. Dalam penelitian ini, leverage dihitung dengan membandingkan total hutang dengan total ekuitas yang dimiliki perusahaan pada tahun bersangkutan.

Growth

$$
\text { LEV }=\frac{\text { Total Hutang }}{\text { Total Ekuitas }}
$$

Menurut Roychowdhury (2006), growth atau pertumbuhan yang dialami perusahaan secara potensial dapat menjelaskan variabel manajemen laba secara signifikan, sehingga proksi growth opportunities digunakan dalam penelitian ini. Pertumbuhan perusahaan dihitung menggunakan market to book equity ratio (MB) dengan membandingkan nilai pasar (MVE) dengan nilai buku ekuitas (BVE), dimana MVE didapat dari volume dikalikan dengan harga saham dan BVE didapat dari volume dikalikan dengan nilai nominal saham.

$$
\mathrm{MB}=\frac{\text { Market value of equity }}{\text { Book value of equity }}
$$

HASIL

\section{Asumsi Klasik \\ Uji Normalitas}

Tabel 1

\begin{tabular}{|c|c|c|}
\hline & & Unstandardized Residual \\
\hline & & 30 \\
\hline Normal Parameters ${ }^{\mathrm{a}, \mathrm{b}}$ & Mean & ,0000000 \\
\hline & Std. Deviation & ,03890801 \\
\hline Most Extreme Differences & Absolute &, 117 \\
\hline & Positive & 105 \\
\hline & Negative &,- 117 \\
\hline Test Statistic & &, 117 \\
\hline Asymp. Sig. (2-tailed) & & $200^{\mathrm{c}, \mathrm{d}}$ \\
\hline
\end{tabular}

One-Sample Kolmogorov-Smirnov Test

Sumber: data olahan

Berdasarkan Tabel 1 besarnya p value adalah 0,200>0,05. Dapat disimpulkan bahwa H0 diterima, sehingga didapatkan hasil data berdistribusi normal dan uji normalitas terpenuhi.

\section{Uji Multikolonieritas}

Uji multikolinearitas bertujuan untuk menguji apakah pada model regresi ditemukan korelasi antar variabel independen (Ghozali, 2011:103). Model regresi yang baik adalah tidak terjadi korelasi di antara variabel independen. Nilai Tolerance $>0,10$ dan nilai VIF < 10, maka tidak terdapat multikolonieritas antar variabel independen dalam model regresi. 


\section{Tabel 2}

Coefficients $^{\mathrm{a}}$

\begin{tabular}{|c|c|c|c|c|c|c|c|c|}
\hline & \multirow[b]{2}{*}{ Model } & \multicolumn{2}{|c|}{ Unstandardized Coefficients } & \multirow{2}{*}{$\begin{array}{c}\text { Standardized } \\
\text { Coefficients }\end{array}$} & \multirow[b]{2}{*}{$\mathrm{t}$} & \multirow[b]{2}{*}{ Sig. } & \multicolumn{2}{|c|}{ Collinearity Statistics } \\
\hline & & B & Std. Error & & & & Tolerance & VIF \\
\hline \multirow[t]{4}{*}{1} & (Constant) & ,993 &, 036 & & 27,703 &, 000 & & \\
\hline & $\begin{array}{l}\text { Corporate Social } \\
\text { responsibility }\end{array}$ & ,066 & 082 & 169 & 805 & ,428 & ,830 & 1,204 \\
\hline & Leverage &,- 011 & ,046 &,- 049 &,- 236 & ,815 & ,861 & 1,161 \\
\hline & Growth & $8,385 \mathrm{E}-6$ & ,000 & ,041 & 203 & ,841 & 910 & 1,098 \\
\hline
\end{tabular}

Sumber: data olahan

Tabel 2 menunjukkan bahwa tidak ada variabel independen yang memiliki nilai Tolerance kurang dari 0,10 , yang berarti tidak terdapat korelasi antar variabel dependen. Nilai VIF juga menunjukkan tidak terdapat variabel independen yang memiliki nilai VIF lebih dari 10. Dapat disimpulkan bahwa tidak terdapat multikolonieritas antar variabel independen dalam model regresi.

\section{Uji Heteroskedastisitas}

Uji heteroskedastisitas bertujuan untuk mengetahui apakah terdapat varian yang sama dari objek yang diteliti. Model regresi yang baik merupakan model yang homokedastisitas atau tidak heteroskedastisitas. Grafik plot antara nilai prediksi variabel terikat (ZPRED) dengan nilai residualnya (SRESID) digunakan untuk uji heteroskedastisitas ini.

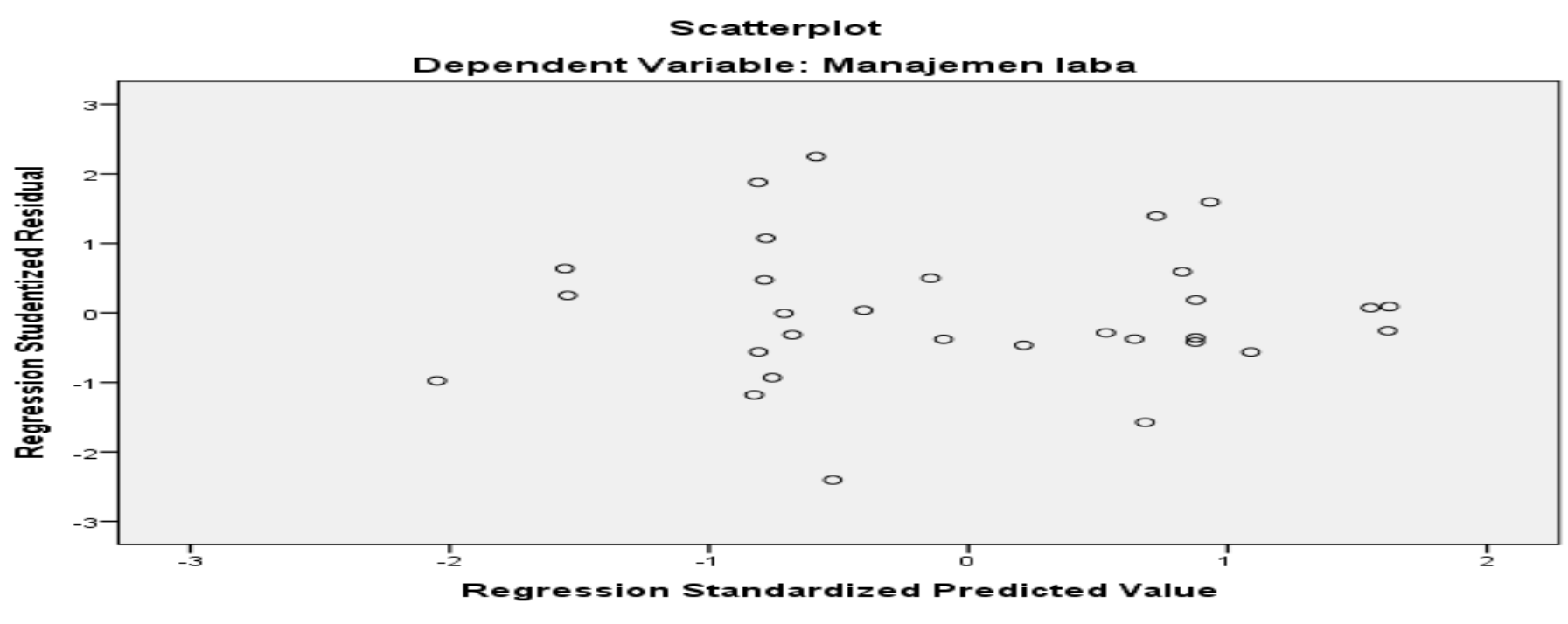

\section{Gambar 1}

Hasil Uji Heteroskedastisitas

Gambar 4.1 menunjukkan bahwa variabel terikat (ZPRED) dengan residualnya (SRESID) menyebar dan tidak membentuk suatu pola tertentu. Hal ini dapat disimpulkan bahwa tidak terjadi heterokedastisitas pada model regresi.

\section{Uji Auotokorelasi}

Uji autokorelasi bertujuan untuk menguji apakah dalam model regresi linear terdapat korelasi antara kesalahan pengganggu pada periode ke ( $\mathrm{t}$ ) dengan periode sebelumnya (t-1). Model regresi yang baik adalah 
model yang tidak memperlihatkan adanya autokorelasi. Durbin Watson (DW) digunakan untuk menguji autokorelasi.

Tabel 3

Model Summary ${ }^{b}$

\begin{tabular}{|c|c|}
\hline Model & Durbin-Watson \\
\hline 1 & 2,754 \\
\hline
\end{tabular}

Sumber: data olahan

Tabel 3 menunjukkan bahwa besarnya Durbin Watson (DW) adalah sebesar 2,754 dengan $\mathrm{N}=30$ dan $\mathrm{K}=4$ (jumlah variabel) dengan nilai $\mathrm{du}=1,64981 \mathrm{dan} 4-\mathrm{du}=2,35019$, nilai $\mathrm{dl}=1,28373$ dan 4-dl $=2,7862$. Nilai dw diantara 4-du dan 4-dl yakni 2,35019 $\leq 2,754 \leq 2,7862$ sehingga menyebabkan tidak menghasilkan kesimpulan yang pasti atas pengujian menggunakan DW test, maka selanjutkan dilakukan uji run test untuk menguji apakah anar residual terdapat korelasi yang tinggi atau tidak, jika antar residual tidak terdapat hubungan korelasi maka dikatakan bahwa residual adalah acak atau random sehingga tidak terdapat masalah auto korelasi, berikut hasil run test :

Tabel 4

Runs Test

\begin{tabular}{|c|r|}
\hline & Unstandardized Residual \\
\hline Test Value $^{\mathrm{a}}$ &,- 00512 \\
Cases $<$ Test Value & 15 \\
Cases $>=$ Test Value & 15 \\
Total Cases & 30 \\
Number of Runs & 18 \\
$\mathrm{Z}$ &, 557 \\
Asymp. Sig. (2-tailed) &, 577 \\
\hline
\end{tabular}

Sumber: data olahan

Hasil run test dari Tabel 4 diatas menunjukkan Asymp. Sig. (2-taied) > 0,05 yang berarti data yang digunakan cukup random sehingga tidak terdapat masalah autokorelasi pada data yang diuji.

\section{Regresi linear Berganda}

Analisis regresi linear berganda digunakan untuk menguji pengaruh variabel independen corporate social reponsibility, variabel kontrol leverage dan control, terhadap variabel dependen manajemen laba.

\section{Tabel 5}

\section{Hasil Analisis Regresi Linear Berganda}

\begin{tabular}{|c|c|c|c|c|c|}
\hline \multirow[b]{2}{*}{ Model } & \multicolumn{2}{|c|}{ Unstandardized Coefficients } & \multirow{2}{*}{$\begin{array}{c}\begin{array}{c}\text { Standardized } \\
\text { Coefficients }\end{array} \\
\text { Beta }\end{array}$} & \multirow[b]{2}{*}{$\mathrm{t}$} & \multirow[b]{2}{*}{ Sig. } \\
\hline & $\mathrm{B}$ & Std. Error & & & \\
\hline (Constant) & ,993 &, 036 & & 27,703 &, 000 \\
\hline Corporate Social responsibility & ,066 & ,082 &, 169 & ,805 & ,428 \\
\hline Leverage &,- 011 & ,046 &,- 049 &,- 236 & ,815 \\
\hline Growth & $8,385 \mathrm{E}-6$ & 000 &, 041 & ,203 & ,841 \\
\hline
\end{tabular}

Sumber: data olahan

Tabel 5 menunjukkan hubungan variabel independen CSR, variabel kontrol leverage dan growth, terhadap variabel dependen manajemen laba. Dapat disimpulkan persamaan regresi yang terbentuk, yaitu: Manajemen Laba $=0,993+0,169 \mathrm{SCR}-0,049$ Leverage $+0,041$ Growth $+\mathrm{e}$ Intepretasi dari persamaan tersebut adalah sebagai berikut: 
a. Jika intensitas CSR, leverage, growth adalah nol, maka manajemen laba adalah 0,993. Maka meskipun tidak dipengaruhi oleh variabel bebas, manajemen laba tetap memiliki nilai yang positif.

b. CSR memiliki koefisien regresi positif sebesar 0,169. Hal ini menunjukkan bahwa setiap kenaikan pengungkapan CSR sebesar 1x, maka manajemen laba akan meningkat sebesar 0,1698.

c. Leverage memiliki koefisien regresi negatif 0,049. Artinya setiap kenaikan leverage 1x, maka manajemen laba akan turun sebesar 0,049 .

d. Growth memiliki koefisien regresi sebesar 0,041. Hal ini menunjukkan bahwa jika growth mengalami kenaikan 1x, maka nilai perusahaan akan meningkat sebesar 0,041 .

\section{Uji Hipotesis}

Uji $F$

Tabel 6

Hasil Uji F

ANOVA $^{\mathrm{a}}$

\begin{tabular}{|c|c|c|c|c|c|c|}
\hline \multicolumn{2}{|c|}{ Model } & Sum of Squares & $\mathrm{df}$ & Mean Square & $\mathrm{F}$ & Sig. \\
\hline 1 & Regression & ,002 & 3 & ,001 &, 392 &, $760^{\mathrm{b}}$ \\
\hline & Residual & ,044 & 26 & ,002 & & \\
\hline & Total & ,046 & 29 & & & \\
\hline
\end{tabular}

Sumber: data olahan

Hasil dari uji F yang dilakukan, diperoleh $\mathrm{F}$ hitung $<\mathrm{F}$ tabel $(0,392<2,98)$. Nilai signifikan adalah 0,760 yang berarti lebih besar dari $0,05(0,760>0,05)$. Dapat disimpulkan bahwa CSR yang dikontrol Leverage dan Growth secara simultan tidak berpengaruh signifikan terhadap manajemen laba.

\section{Uji $t$}

Uji t digunakan untuk mengetahui pengaruh variabel independen terhadap variabel dependen. Pengujian uji t menggunakan nilai siginifikansi $0,05(\alpha=0,05)$, dengan ketentuan $\operatorname{sig}<\alpha$, maka variabel independen berpengaruh secara signifikan terhadap variabel dependen.

Tabel 7

Hasil Uji t

\begin{tabular}{|c|c|c|c|c|c|c|}
\hline \multirow{2}{*}{\multicolumn{2}{|c|}{ Model }} & \multicolumn{2}{|c|}{ Unstandardized Coefficients } & $\begin{array}{l}\text { Standardized } \\
\text { Coefficients }\end{array}$ & \multirow[b]{2}{*}{$\mathrm{T}$} & \multirow[b]{2}{*}{ Sig. } \\
\hline & & $\mathrm{B}$ & Std. Error & Beta & & \\
\hline \multirow[t]{4}{*}{1} & (Constant) & ,993 &, 036 & & 27,703 & 000 \\
\hline & Corporate Social responsibility & 066 & 082 & ,169 &, 805 & ,428 \\
\hline & Leverage &,- 011 & ,046 &,- 049 &,- 236 &, 815 \\
\hline & Growth & $8,385 \mathrm{E}-6$ & ,000 & 041 & 203 & 841 \\
\hline
\end{tabular}

Hasil uji pada Tabel 7 menunjukkan bahwa:

a) Besarnya nilai t hitung CSR 0,805 (< dari t tabel 2,05553) dengan signifikansi sebesar 0,(>0,05), dapat disimpulkan CSR tidak berpengaruh signifikan terhadap manajemen laba.

b) t hitung pada variabel leverage negatif $(0,236)$. Nilai signifikansi 0,815 dapat disimpulkan leverage berpengaruh negatif tidak signifikan terhadap manajemen laba

c) Variabel Growth memiliki t hitung sebesar 0,203 dengan signifikansi 0,841, dapat disimpulkan growth tidak berpengaruh signifikan terhadap manajemen laba. 


\section{Koefisien Determinasi}

Tabel 8

Hasil Uji Determinasi

\begin{tabular}{|c|c|c|c|c|c|}
\hline Model & $\mathrm{R}$ & R Square & Adjusted R Square & $\begin{array}{l}\text { Std. Error of the } \\
\text { Estimate }\end{array}$ & Durbin-Watson \\
\hline 1 &, $208^{a}$ &, 043 &,- 067 &, 04109 & 2,754 \\
\hline
\end{tabular}

Sumber: data olahan

Terlihat pada tabel 4.9 Nilai $\mathrm{R}^{2}$ sebesar 4,3\%, dimana hal ini menjelaskan bahwa CSR, Leverage, dan Growth mempengaruhi manajemen laba sebesar 4,3\%. Sisanya sebesar 95,7\% dipengaruhi variabel lain.

\section{SIMPULAN}

a. Hasil penelitian menunjukkan Corporate social responsibility memiliki pengaruh positif tidak signifikan terhadap manajemen laba. Setiap terdapat kenaikan pada pengungkapan CSR, maka manajemen laba juga akan meningkat.

b. Hasil penelitian menunjukkan bahwa Corporate social responsibility, leverage, dan growrth secara parsial tidak berpengaruh signifikan terhadap manajemen laba.

\section{DAFTAR PUSTAKA}

Adisetiawan, R., dan Surono, Yunan,. 2016, Earning Managemen and Accounting Information Value: Impact and Relevance, Business, Management and Economics Research, 2(10), 170-179

Adisetiawan, R., 2011, Relevansi Nilai Informasi Akuntansi pada Indeks LQ45, Jurnal Akuntabilitas, 1(1), $119-136$

Arna, Suryani. 2016. Financial Statements Conservatism Effect on Earning Response Coefficient and Earning Management. International Journal of Economic Research (IJER).

Arna, Suryani dan Eva Herianti. 2015. Pengaruh pengungkapan Tanggung jawab sosial perusahaan terhadap Koefisien respon laba dan manajemen laba ( Studi Empiris pada Perusahaan manufaktur yang terdaftar di Bursa Efek Indonesia. SNA 18, Medan.

Arvina Arif dan Moh. Didik Ardiyanto. 2014. Pengaruh pengungkapan corporate social responsibility terhadap manajemen laba. Diponegoro journal of avvouning. Vol.3 Nomor.3.ISSN (Online):2337-3806.

Chih, H., C. Shen., and F. Kang. 2008. Corporate social responsibility, investor protection, and earnings management: some international evidence, Journal of Business Ethics: 79:179-198.

Dhiba Meautya Chancera. 2011. Pengaruh Manajemen Laba terhadap Biaya Modal Ekuitas Pada Perusahaan Manufaktur yang Terdaftar di Bursa Efek Indonesia Tahun 2008-2009. Skripsi UNDIP.

Ghozali, Imam. 2011. "Aplikasi Analisis Multivariate Dengan Program SPSS”. Semarang: Badan Penerbit Universitas Diponegoro.

Kim, Y., Park, M. S., \& Wier, B. (2012). Is earnings quality associated with corporate social responsibility? The Accounting Review, 87(3), 761-796.

Nastiti, Amalia Rudi. 2010. Pengaruh Corporate Social Responsibility Terhadap Manajemen Laba (Studi pada Perusahaan Manufaktur yang Listing di Bursa Efek Indonesia Periode 2005- 2008). Skripsi Pogram Sarjana Universitas Negeri Malang, Jawa Timur.

Scott, Wilson, 2007. Financial Accounting Theory $3^{\text {rd }}$ Edition, Prentice Hall.

Watts, Ross L. and Jerold L. Zimmerman. 1978. Positive Accounting Theory. New Jersey. Prentice Hall International, Inc.

Widyaningdyah, 2004. Analisa Faktor-faktor yang Mempengaruhi Pilihan Perusahaan terhadap Akuntansi Konservatif. Dipresentasikan di Simposium Nasional Akuntansi, Denpasar.

Salno, H. M., dan Zaki Baridwan, 2000. Analisis Perataan Penghasilan ( Income Smoothing): Faktor-faktor yang mempengaruhi dan Kaitannya dengan Kinerja Saham Perusahaan di Indonesia. Jurnal Riset Akuntansi Indonesia, Januari Vol. 3: 17-34. 
Prior, Diego, Jordi Surroca and Josep A. Tribo, 2007. Earning management and Corporate Social Responsibility, Working Paper 06-23. Business Economics series 06, September.

Yip, Erica; Van Staden, Chris; and Cahan, Steven, "Corporate Social Responsibility Reporting and Earnings Management: The Role of Political Costs". Australasian Accounting Business and Finance Journal, 5(3), 2011, 17-34. 